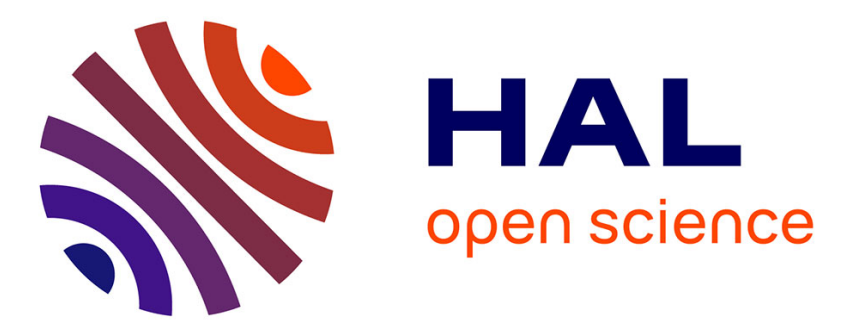

\title{
Integrated optimal design and sensitivity analysis of a stand alone wind turbine system with storage for rural electrification
}

\author{
Malek Belouda, Amine Jaafar, Bruno Sareni, Xavier Roboam, Jamel Belhadj
}

\section{- To cite this version:}

Malek Belouda, Amine Jaafar, Bruno Sareni, Xavier Roboam, Jamel Belhadj. Integrated optimal design and sensitivity analysis of a stand alone wind turbine system with storage for rural electrification. Renewable and Sustainable Energy Reviews, 2013, 28, pp.616-624. hal-00873030

\section{HAL Id: hal-00873030 \\ https://hal.science/hal-00873030}

Submitted on 15 Oct 2013

HAL is a multi-disciplinary open access archive for the deposit and dissemination of scientific research documents, whether they are published or not. The documents may come from teaching and research institutions in France or abroad, or from public or private research centers.
L'archive ouverte pluridisciplinaire HAL, est destinée au dépôt et à la diffusion de documents scientifiques de niveau recherche, publiés ou non, émanant des établissements d'enseignement et de recherche français ou étrangers, des laboratoires publics ou privés. 


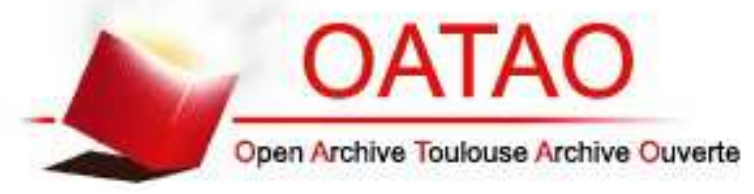

\section{Open Archive TOULOUSE Archive Ouverte (OATAO)}

OATAO is an open access repository that collects the work of Toulouse researchers and makes it freely available over the web where possible.

This is an author-deposited version published in : http://oatao.univ-toulouse.fr/ Eprints ID : 9348

To link to this article : DOI:10.1016/j.rser.2013.08.042

URL : http://dx.doi.org/10.1016/j.rser.2013.08.042

To cite this version : Belouda, Malek and Jaafar, Amine and Sareni, Bruno and Roboam, Xavier and Belhadj, Jamel Integrated optimal design and sensitivity analysis of a stand alone wind turbine system with storage for rural electrification. (2013) Renewable and Sustainable Energy Reviews, 28 . pp. 616-624. ISSN 1364-0321

Any correspondance concerning this service should be sent to the repository administrator: staff-oatao@ listes-diff.inp-toulouse.fr 


\title{
Integrated optimal design and sensitivity analysis of a stand alone wind turbine system with storage for rural electrification
}

\author{
M. Belouda ${ }^{\mathrm{a}, \mathrm{b}, *}$, A. Jaafar ${ }^{\mathrm{c}}$, B. Sareni ${ }^{\mathrm{c}}, \mathrm{X}$. Roboam ${ }^{\mathrm{c}}, \mathrm{J}$. Belhadj ${ }^{\mathrm{a}, \mathrm{b}}$ \\ a University of Tunis, DGE-ESSTT, Tunisia \\ ${ }^{\mathrm{b}}$ University of Tunis El Manar, ENIT, L.S.E.B.P. 37, 1002 Tunis, Tunisia \\ ${ }^{\mathrm{C}}$ Université de Toulouse, LAPLACE UMR CNRS-INP-UPS, ENSEEIHT 2, Rue Charles Camichel 31071, Toulouse, France
}

Keywords:

Passive wind turbine

Systemic optimization

Integrated Optimal Design

Battery cycles

Total cost of ownership

Sensitivity analysis

\begin{abstract}
In this paper, the authors investigate a robust Integrated Optimal Design (IOD) devoted to a passive wind turbine system with electrochemical storage bank: this stand alone system is dedicated to rural electrification. The aim of the IOD is to find the optimal combination and sizing among a set of system components that fulfils system requirements with the lowest system Total Cost of Ownership (TCO). The passive wind system associated with the storage bank interacts with wind speed and load cycles. A set of small power passive wind turbines spread on a convenient power range $(2-16 \mathrm{~kW})$ are obtained through an IOD process at the device level detailed in previous papers. The system cost model is based on data sheets for the wind turbines and related to battery cycles for the storage bank. From the range of wind turbines, a "system level" optimization problem is stated and solved using an exhaustive search. The optimization results are finally exposed and discussed through a sensitivity analysis in order to extract the most robust solution versus environmental data variations among a set of good solutions.
\end{abstract}

\section{Contents}

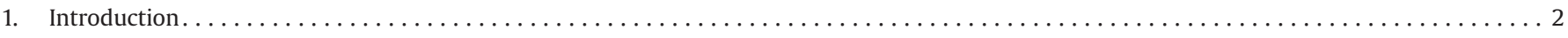

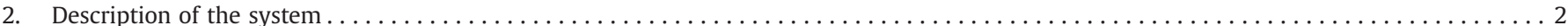

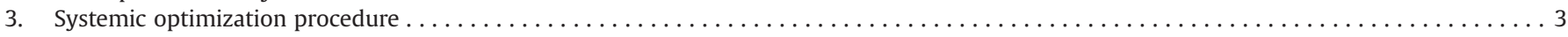

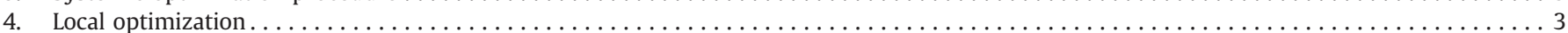

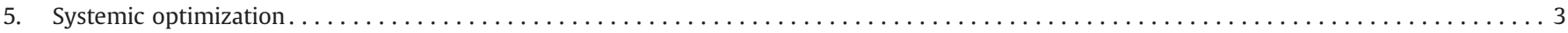

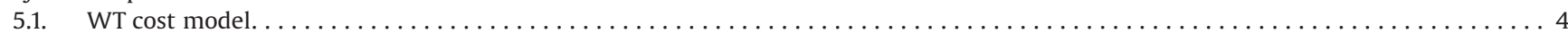

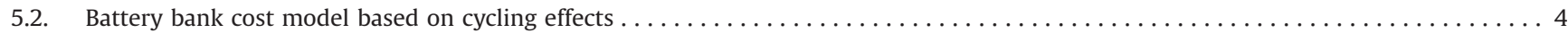

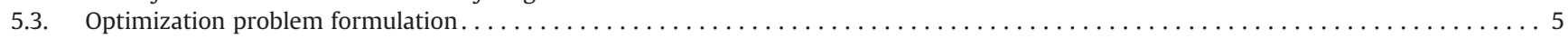

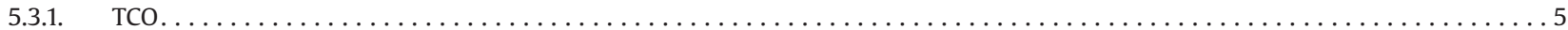

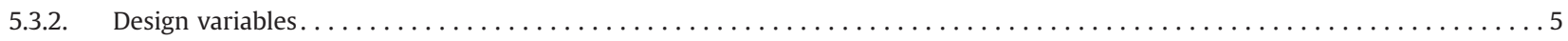

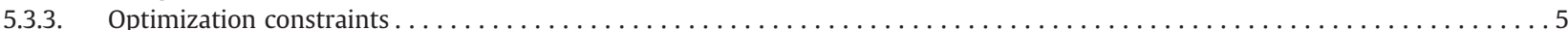

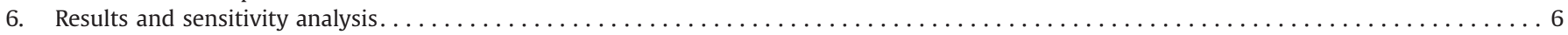

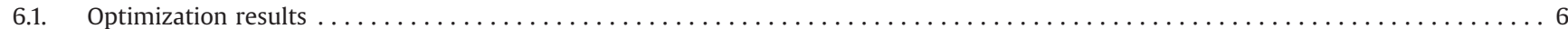

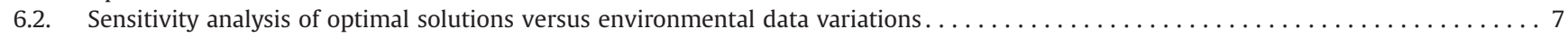

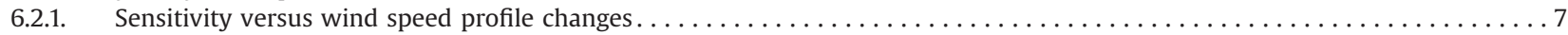

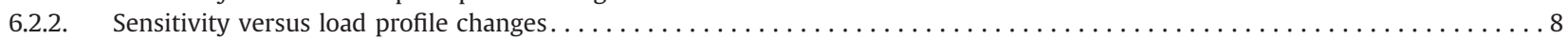

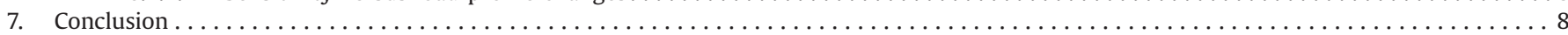

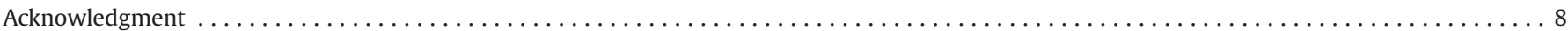

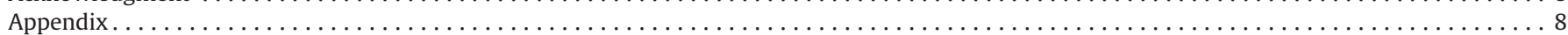

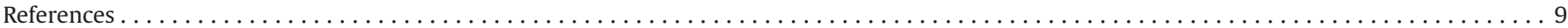

\footnotetext{
* Correspondence to: School of Sciences and Technology of Tunis (ESSTT), 5 Avenue Taha Hussein, (B.P. 56 Bab Menara), 1008 Montfleury-Tunis, Tunisia. Tel.: +21699614114.

E-mail address: malek.belouda@gmail.com (M. Belouda).
} 


\begin{tabular}{|c|c|c|c|}
\hline \multicolumn{2}{|c|}{ Nomenclature } & $N_{c e l \_s}$ & number of cells in series \\
\hline$c$ & scale factor $(\mathrm{m} / \mathrm{s})$ & $N_{c y c}$ & equivalent number of cycles \\
\hline$C_{0}$ & cost of one deep battery cycle $(€)$ & $N_{c y c}^{\tau}$ & equivalent number of cycles \\
\hline$C_{3}$ & battery element nominal capacity (Ah) & $P_{\text {ext }}$ & extracted power (W) \\
\hline$C_{B A T}$ & battery bank cost $(€)$ & $P_{\text {load }}$ & load power (W) \\
\hline$C_{\text {Cell }}$ & battery cell cost $(€)$ & $P_{W T}$ & wind turbine nominal power $(\mathrm{W})$ \\
\hline$C_{F}$ & cycle to failure & SOC & battery cell state of charge \\
\hline$C_{W T}$ & wind turbine cost $(\mathrm{k} €)$ & $T_{\text {aut }}$ & battery bank time autonomy $(\mathrm{h})$ \\
\hline$D O D$ & depth of discharge & TCO & total cost of ownership $(\mathrm{k} €)$ \\
\hline$I_{3}$ & battery element nominal discharge current $(\mathrm{A})$ & $V_{0}$ & battery element nominal voltage (V) \\
\hline & battery cell current $(\mathrm{A})$ & $V_{1,2,3}$ & generated wind speed $(\mathrm{m} / \mathrm{s})$ \\
\hline$I_{\text {ch_max }}$ & battery cell maximum charge current $(\mathrm{A})$ & $V_{r e f}$ & reference compact wind speed $(\mathrm{m} / \mathrm{s})$ \\
\hline$I_{\text {disch_max }}$ & battery cell maximum discharge current (A) & $V_{\text {wind }}$ & wind speed $(\mathrm{m} / \mathrm{s})$ \\
\hline$k$ & shape factor & $w_{c y c}$ & weight of a cycle \\
\hline N & number of cycles at a given $D O D$ & $\tau$ & repeated wind cycle (days) \\
\hline$N_{c e l \_p}$ & number of cells in parallel & $\tau_{o p}$ & operating period (days) \\
\hline
\end{tabular}

\section{Introduction}

According to the World Energy Agency [1], some 1.5 billion people had no access to electricity in the world by 2009, with more than $80 \%$ of habitants in rural zones. Providing consumers in remote areas with reliable and cheap electricity becomes a priority in several developed and undeveloped countries such as in the case of isolated cities in Tunisia. The steadily increasing demand of fossil fuels along with concerns about global warming, presents natural renewable energy sources as attractive solutions. Among these sources wind energy systems (free in their availability, renewable and non-polluting) with storage are among the most competitive alternatives for electrifying remote consumers and they are widely used in both autonomous or grid connected applications. These systems can also operate in parallel with others available energy sources (fuel cells, diesel generators) and several means of storage (accumulators, $\mathrm{H}_{2}$ storage, etc.) in order to enhance the system reliability [2-5].

However, the drawbacks of such sources are their TCO which is still expensive, especially for small wind turbine systems. Moreover to assure the service continuity and to protect the battery against deep discharges (subsequently extend the battery bank life), such systems require an additional dynamic source of energy or an optimal wind system design $[8,9]$ ). Recently, several researches based on global optimization techniques have been focused on the design of optimal system configurations which meet the load demand for given climatic data [10-12].

Bagul, Borowy and Salameh [6-8] have developed several methodologies for optimally sizing a wind/PV system associated with a battery bank for a given load. These methods are based on the use of long term data for both irradiance and wind speed. However, such approaches are penalized by CPU time due to wide data range. Several studies have used the average hourly wind speed data over a few years simulation period, but this vision strongly filters wind turbine powers. Other researchers $[13,14]$ have developed probabilistic methods to determine the annual energy of a wind system. In particular in [15-19], authors have selected the optimal combination and sizing of wind generators, PV modules and storage batteries.

This paper suggests a systemic methodology for designing the optimal combination and sizing of passive wind turbines associated with electrochemical storage. Generally, deterministic optimization approaches neglect the effects of environmental inputs uncertainties (including variation or perturbation of wind speed and/or load profiles) which can lead to drastic change of optimal solution quality. Several studies [20-26] have taken into account the increased need for sensitivity analyses to perform a robust system design in various research areas.Thus, this study is particularly focused on the sensitivity analysis of a set of "good" solutions to obtain an optimum system quite insensitive to environmental variations.

The remaining of the paper is organized as follows. The passive wind system and the battery characteristics are described in Section 2. In the third section, the systemic optimization procedure is presented. Section 4 is dedicated to the local optimization procedure. The models and the systemic optimization formulation are exposed in Section 5. Section 6 is reserved to the results and the sensitivity analysis.

\section{Description of the system}

The considered system is a "low cost" full passive wind turbine (WT) battery charger (Fig. 1) without active control and with minimum number of sensors as studied in $[27,28]$ : this local optimization loop is not detailed in this paper but only referred to previous studies. An experimental prototype of the optimized system, especially the PM synchronous generator, has been built in LAPLACE Lab and had confirmed the ability of the passive structure to draw a power close to the optimal range with small losses. This prototype and subsequent study is detailed in [29]. The wind turbine parameters have been obtained by applying similitude relationships with reference to a $1.7 \mathrm{~kW}$ wind turbine which had been previously optimized by the local IOD process in [30,31].

Both wind speed and load profiles used in this study are considered as deterministic data. These data were acquired at a typical farm in Tunisia. The load profile is set on $24 \mathrm{~h}$ and day by day repeated (Fig. 2). The wind speed profile has been obtained from a previous study [32] by applying a "compact synthesis process" on an actual wind speed profile of 200 days duration considered as reference data, with the aim of generating a

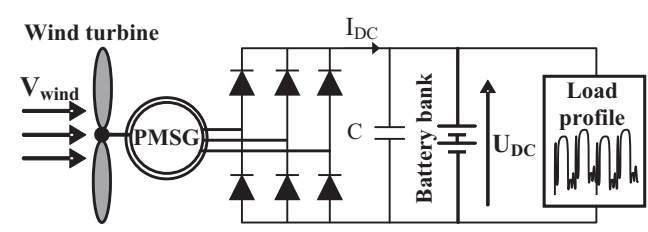

Fig. 1. WT system with battery for stand alone application (rural site electrification). 


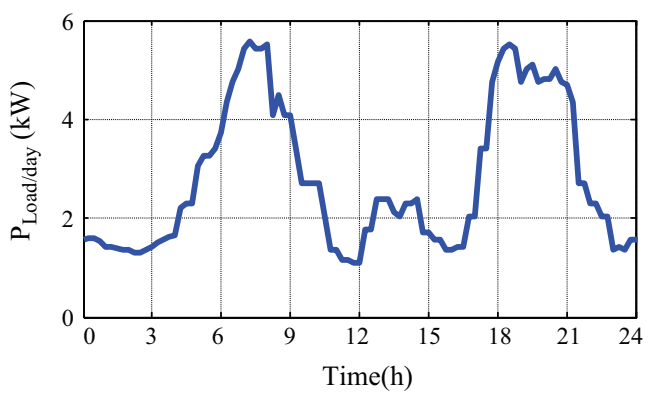

Fig. 2. Typical farm load profile for one day.

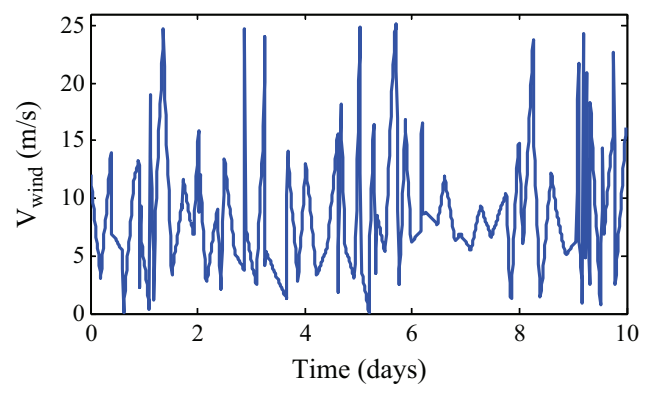

Fig. 3. Wind speed compact profile.

Table 1

Basic characteristics of a Yuasa NP 38-12I lead acid battery element.

\begin{tabular}{ll}
\hline Nominal capacity $C_{3}$ & $30.3(\mathrm{Ah})$ \\
Nominal voltage $V_{0}$ & $12(\mathrm{~V})$ \\
Nominal discharge current $I_{3}$ & $10.1(\mathrm{~A})$ \\
\hline
\end{tabular}

compact profile on a reduced duration of 10 days (Fig. 3) to accelerate the optimization process. It should be noted that this process synthesizes a wind cycle which fulfils the main characteristics of the reference cycle on 200 days, especially the maximum wind speed, the average cubic wind speed and the energy content of the wind cycle [32].

In this study, a lead acid Yuasa NP 38-12I [33] is considered as battery element. The basic characteristics are summarized in Table 1.

$\mathrm{NB}$ : in the following, let us note that the $12 \mathrm{~V}$ Yuasa "battery element" is constituted of 6 "cells" of $2 \mathrm{~V}$ in series. The association of several "battery elements" ( $12 \mathrm{~V})$ in series and in parallel will be named as "battery bank".

\section{Systemic optimization procedure}

In order to perform the optimization of the whole system including the passive WT and the storage battery considering wind speed and consumption profiles, we have adopted an approach based on two optimization levels:

Level 1 Systemic Optimization (SO) of the whole system. Level 2 Local Optimization (LO) of the WT device.

Given a wind speed profile, the SO approach consists in selecting a WT in the range normally provided by the WT manufacturer (WT $T_{1}-T_{n}$ and the corresponding Permanent Magnet Synchronous Generator (PMSG) $G_{1}-G_{n}$ : in our case, these devices are obtained from the LO process as presented in [31]). The couple $\left(T_{i}, G_{i}\right)$ and the corresponding storage sizing have to satisfy a given load demand at lowest TCO. This compromise can

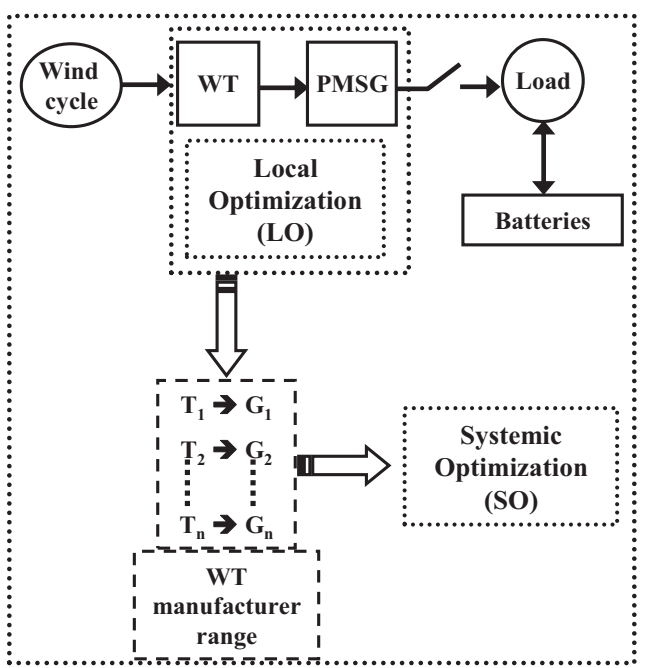

Fig. 4. Systemic Optimization process.

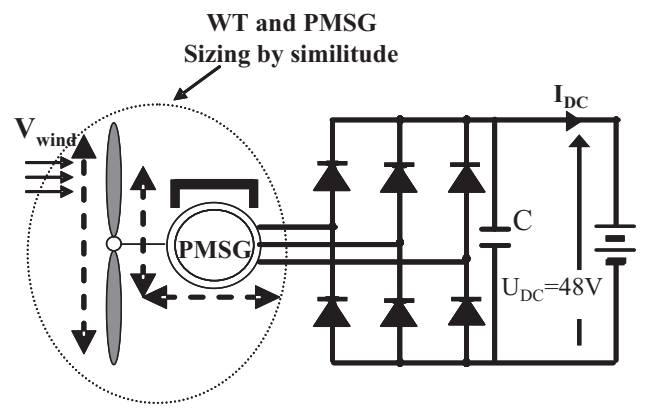

Fig. 5. Passive WT synoptic.

be obtained by solving the optimization problem illustrated in Fig. 4.

\section{Local optimization}

The aim of this second optimization level is to build a range of $n$ generators corresponding to $n$ WTs which will be used in the first optimization level (systemic approach). In this approach, the battery bank voltage is as constant and equal to $48 \mathrm{~V}$ (i.e. a series connection of 4 Yuasa $12 \mathrm{~V}$ elementary batteries) (Fig. 5).

The "mixed reduced model" considered in this optimization process is detailed in $[27,31]$.

In [31], an IOD method, based on a multiobjective optimization, has been developed for sizing the elements of a $1.7 \mathrm{~kW}$ passive wind turbine system. The WT range with related generator parameters for various nominal powers has been obtained by applying similitude relationships with reference to the $1.7 \mathrm{~kW}$ wind turbine system [30]. Fig. 6 shows the extracted powers $P_{\text {ext }}$ of the passive wind turbines (till $16 \mathrm{~kW}$ ) obtained by similitude from the optimized reference passive wind turbine of $1.7 \mathrm{~kW}$ (Appendix). It can be seen that the quality of wind power extraction of these passive configurations (solid curves) matches very closely the behavior of active wind turbine systems operating at optimal wind powers by using an MPPT control device (i.e. the cubic curves in Fig. 6). It should be noted that the selected wind turbine range (1.7 up to $16 \mathrm{~kW}$ ) is constrained by the average load power $\left\langle P_{\text {load }}\right\rangle$, since we have adopted a range between $1 / 2\left\langle P_{\text {load }}\right\rangle$ and $5\left\langle P_{\text {load }}\right\rangle$. Furthermore, the use of similitude models from a reference wind turbine device of $1.7 \mathrm{~kW}$ limits the range of power expansion to fulfill validity domain of similitude relationships. 

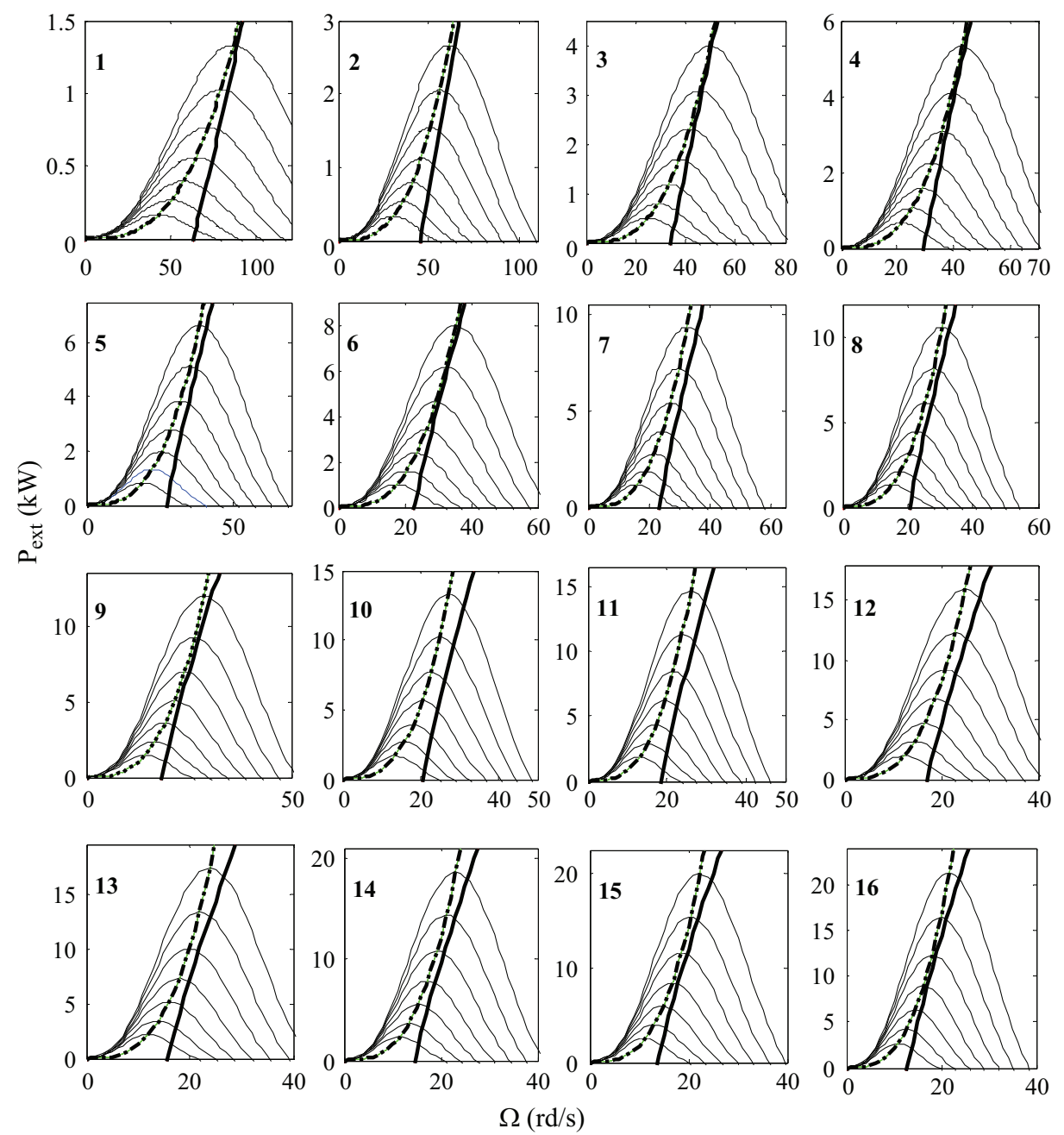

Fig. 6. Extracted power of the range of passive WT systems obtained by similitude from the reference $1.7 \mathrm{~kW}$ WT.

\section{Systemic optimization}

The aim of the SO stage is the minimization of the TCO on a life cycle of 20 years of the passive WT coupled with a storage bank ensuring the electrification of the isolated farm under a specific compact wind speed cycle [32]. To achieve this optimization process, a cost model of each system component has to be determined.

\subsection{WT cost model}

Generally, the WT subsystem is composed of a turbine, a nacelle, a tower, a rectifier, a mechanical transmission system. There is no single component that dominates the WT cost. Typical owning costs given by "eaglewestwind" [34] for a range of turbines from $2 \mathrm{~kW}$ up to $20 \mathrm{~kW}$ are shown in Fig. 7: system costs include costs due to all components of the device. A linear interpolation of these costs has led to the following WT cost model:

$C_{W T}=1.7 P_{W T}+3$

The lifetime of WTs being assumed to be at least 20 year, the owning cost of WTs will simply be due to the investment cost, which assumes that no maintenance costs are needed due to the robustness of the full passive wind turbine structure. Such assumption can be justified for low power wind turbines, especially as the passive structure is particularly robust.

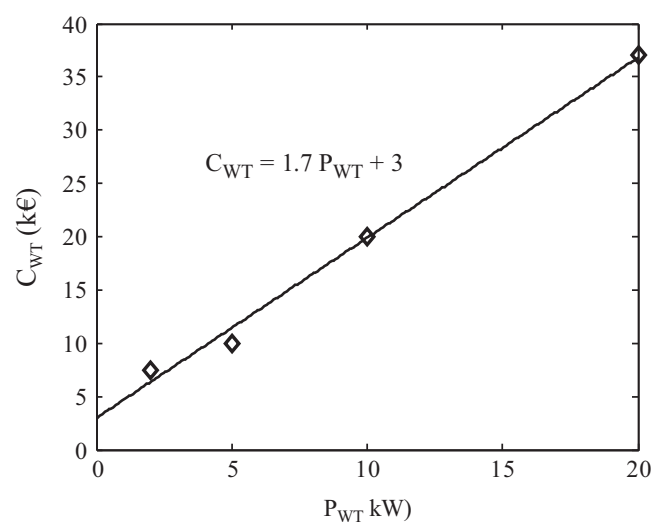

Fig. 7. Assumption of a WT cost model versus rated power $P_{W T}$.

\subsection{Battery bank cost model based on cycling effects}

The battery cost depends on the charge and discharge cycling in terms of number and cycle depth that the battery can provide (battery lifetime strongly depend on both depth and rate of discharge). The equivalent number of cycles $\left(N_{c y c}\right)$ is obtained by a weighted sum of the cycles in terms of their depth of discharge $(D O D)$. The weights are derived from the manufacturer curve giving the number of complete cycles that the storage element is 
capable of delivering in terms of its $D O D$ (characteristic called "cycle to failure").

The lifetime model, for Yuasa NP 38-12I lead acid battery, uses an exponential curve fitting based on the available cycle to failure $\left(C_{F}\right)$ curve (Fig. 8) versus $D O D$ [35,36,37]:

$C_{F}=177.77+7807.39 \cdot e^{-6.75 \cdot D O D}$

Considering the number of cycles provided by the battery with a DOD of $100 \%$ as a reference, the weight of a cycle depth DOD $\left(w_{c y c}(D O D)\right)$ is expressed by the following equation:

$w_{c y c}(D O D)=\frac{C_{F}(100 \%)}{C_{F}(D O D)}$

Thus, the equivalent number of cycles is obtained by:

$N_{c y c}=\sum_{D O D} w_{c y c}(D O D) \times N(D O D)$

where $N(D O D)$ is the number of cycles at a given $D O D$ obtained by the Rainflow method.

For an operating period $\tau_{o p}$ of 20 years and a repeated wind cycle $\tau$ of 10 days, the approximate cost of the battery bank, taking account of cycling constraints over 20 years, is expressed by the following equation:

$C_{B A T}(k €)=\mathrm{N}_{\text {cel_s }} N_{\text {cel_p }} C_{0} \times 10^{-3} N_{c y c}^{\tau} \frac{\tau_{o p}}{\tau}$

where $N_{\text {cel_s }}$ is the number of battery cells of $2 \mathrm{~V}$ associated in series (here considered as constant and equal to 24 to constitute a battery of $48 \mathrm{~V}$ ), $N_{\text {cel_p }}$ is the number of battery cells associated in parallel and $C_{0}$ is the cost of one deep battery cycle $(D O D=100 \%)$ estimated at $0.1 €[33]$. This latter cost comes from the Yuasa $12 \mathrm{~V}$ battery element cost which is $108 €$. Then, the $2 \mathrm{~V}$ battery cell cost is $C_{\text {Cell }}=108 / 6 €$ for 180 allocated deep cycles. Finally, one cell deep cycle cost is $C_{\text {Cell }} / 180=0.1 €$.

It should also be noted that the initial purchase cost of the battery $C_{B A T 0}$ is defined as following:

$C_{\text {BAT0 }}(k €)=\mathrm{N}_{\text {cel_s }} N_{\text {cel_p }} C_{\text {Cell }} \times 10^{-3}$

\subsection{Optimization problem formulation}

The problem is to develop a systemic approach that allows optimizing system configurations (passive WT with storage bank) that satisfy load power demand with minimum TCO. The TCO calculation includes the WT owning cost and battery bank owning cost. The systemic optimization process is detailed in Fig. 9. By means of the compacted wind cycle obtained from the synthesis process proposed in [32] (as presented in Fig. 3), only 10 days of system operation have to be simulated in this optimization process. Results obtained from this typical but representative

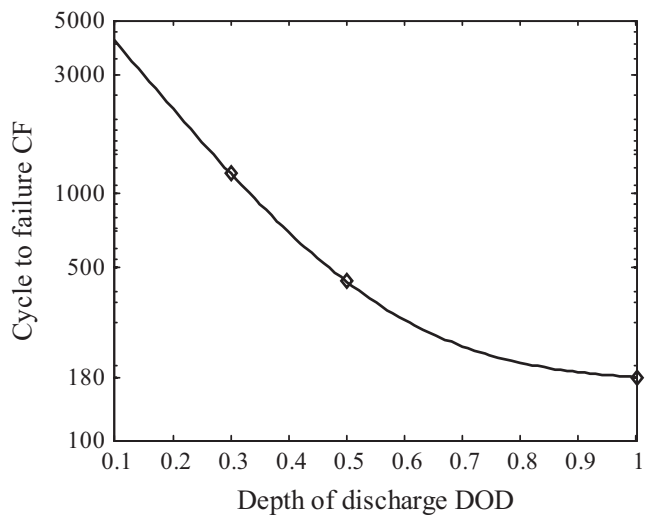

Fig. 8. Cycle to failure curve for Yuasa accumulator cell.

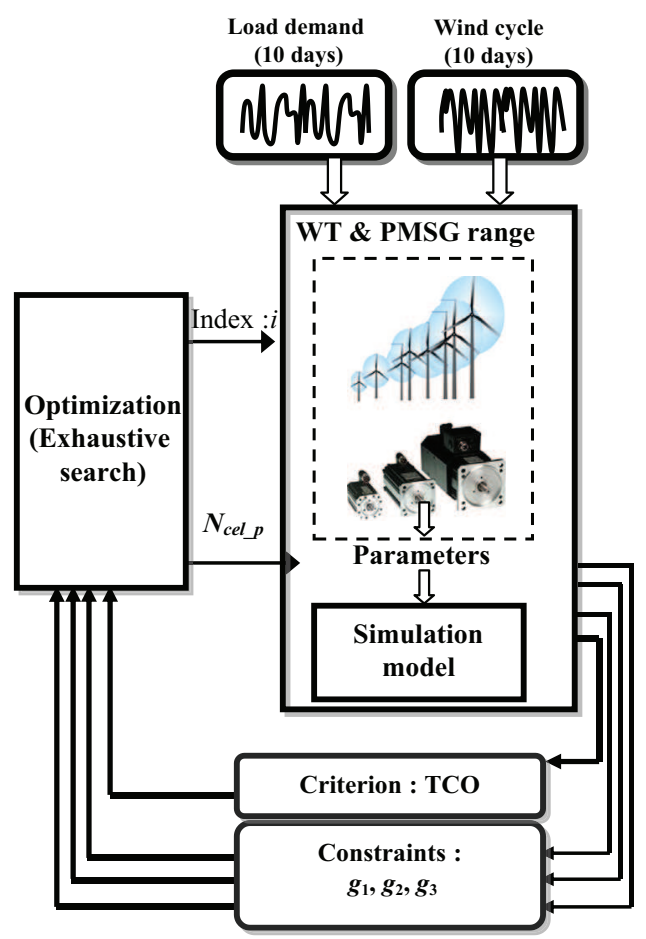

Fig. 9. Systemic process of optimal design.

compact profile are then extrapolated over 20 years in order to estimate the TCO due to cycling effects.

\subsubsection{TCO}

A single objective function is used consisting in the TCO which includes WT and battery bank owning costs over a duration period of 20 years.

$T C O=C_{W T}+C_{B A T}$

\subsubsection{Design variables}

The optimization problem only uses two discrete design variables:

- $N_{c e l \_}$: The number of battery cells associated in parallel $\left(N_{c e l-s}\right.$ being the number of battery cells $(2 \mathrm{~V})$ in series is fixed at 24 for a $48 \mathrm{~V}$ battery bank).

- index $i$ : This index identifies the couples of turbines and associated generators $\left(T_{i}\right.$ and $\left.G_{i}\right)$ used in the simulation model for computing the system TCO and the optimization constraints. Note also that this index corresponds with power level (in kW) of the WT.

\subsubsection{Optimization constraints}

- $g_{1}$ : is a constraint related to the maximum discharge current (I Iisch_max $)$.

The battery cell maximum discharge current $\left(\max \left(I_{c e l}\right)\right)$, must be less than the current $I_{\text {disch_max: }}$

$g_{1}=\max \left(I_{\text {cel }}\right)-I_{\text {disch_max }} \leq 0$

- $g_{2}$ : is a constraint related to maximum charge current $\left(I_{\text {ch_max }}\right)$. The absolute value of the maximum battery cell charge current $\left(\left|\min \left(I_{\text {cel }}\right)\right|\right)$ must be less than the current $I_{\text {ch_max }}$ :

$g_{2}=\min \left(I_{c e l}\right)-I_{c h \_} \max \leq 0$

Note that charge/discharge current are respectively considered as negative/positive. 
- $g_{3}$ : is a constraint related to the battery cell state of charge $(S O C)$.

The minimum value of the battery cell state of charge min(SOC ( $t)$ ) must be greater than $20 \%$ :

$g_{3}=20 \%-\min (\operatorname{SOC}(t)) \leq 0$

In this study, $I_{\text {disch_max }}$ and $I_{\text {ch_max }}$ have been chosen equal to the nominal discharge current $I_{3}=10.1 \mathrm{~A}$ (Table 1 ).

As defined, the optimization problem is sufficiently simplified (one objective, two design variables and three constraints) to justify the use of an exhaustive search $(80.14=1120$ combinations $)$ instead of adopting more sophisticated optimization algorithms. Other approaches may be used in more complex case study, as for hybrid systems with several sources. Note also that this simplified and efficient optimization problem is mainly due to the structure of the design process with 2 loops, one for the WT device and another one for systemic approach.

\section{Results and sensitivity analysis}

\subsection{Optimization results}

Fig. 10 shows a set of solutions resulting from the systemic optimization process, corresponding to a TCO lower than $115.5 \mathrm{k} €$. It should be observed that the TCO range is displayed with a reduced scale $(1 / 115 \mathrm{k} €)$ so that TCOs of these solutions can be considered as quasi-equivalent. Each point corresponds to one solution, (i.e. one couple of variables: index $i$ representing the WT rated power and $\left.N_{c e l-p}\right)$. The cheapest solution (circled in Fig. 10) corresponds to a configuration with 63 branches in parallel (i.e. 252 "12 V Yuasa battery elements" for the battery bank) with a WT of $13 \mathrm{~kW}$ of nominal power $(i=13)$. Table 2 gives the different characteristics of some quasi-equivalent optimal solutions and Fig. 11 shows the state of charge SOC and the battery cell current $\left(I_{c e l}\right)$ evolutions of the solution Sol $13_{\text {opt }}$. One can see that a reduced DOD range is obtained from that optimal sizing taking account of cycling effect on system costs.

Table 2

Quasi-equivalent optimal solutions characteristics.

\begin{tabular}{lccccccc}
\hline & Sol & Sol & Sol & Sol & Sol & Sol & Sol \\
& $16(\mathrm{a})$ & $16(\mathrm{~b})$ & 12 & $13(\mathrm{a})$ & $1_{\mathrm{opt}}$ & $15(\mathrm{a})$ & $15(\mathrm{~b})$ \\
\hline$N_{\text {cel_p }}$ & 49 & 59 & 61 & 62 & 63 & 69 & 79 \\
$C_{W T}(\mathrm{k} €)$ & 30 & 30 & 23 & 25 & 25 & 28.5 & 28.5 \\
$N_{C Y C}$ (on 20 years) & 714 & 594 & 622 & 602 & 589 & 520 & 452 \\
$C_{\text {BAT }}(\mathrm{k} €)$ & 84.1 & 84.2 & 91 & 89.7 & 89.1 & 86.2 & 85.8 \\
$T C O(\mathrm{k} €)$ & 114.3 & 114.4 & 114.5 & 114.8 & 114.2 & 114.7 & 114.3 \\
$C_{\text {BATO }}(\mathrm{k} €)$ & 21 & 25.4 & 26.3 & 26.7 & 27.2 & 29 & 34.1 \\
$N_{C H}$ (on 20 years) & 3 & 3 & 3 & 3 & 3 & 2 & 2 \\
\hline
\end{tabular}

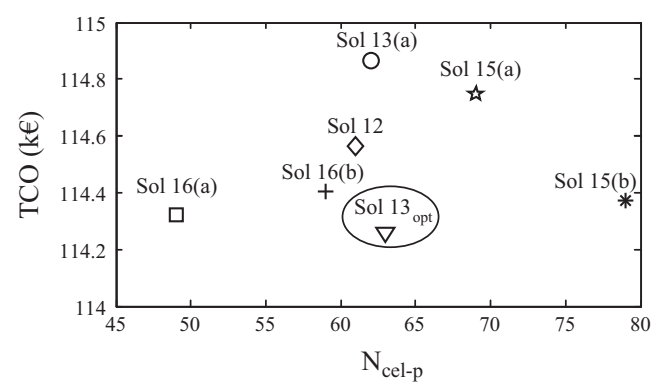

Fig. 10. Similar solutions with equivalent TCO.
Note that $N_{C H}$ is the number of the battery bank changes necessary for 20 years. $N_{C H}$ can be calculated from (5) and (6) by deriving the following equation:

$N_{C H}=\left\lfloor\frac{C_{B A T} \text { over } 20 \text { years }}{C_{B A T 0}}\right\rfloor$

Another criterion necessary for the optimal solutions analysis is the battery bank autonomy time $T_{\text {aut }}$ of each solution. This time is defined as the corresponding duration of a complete battery discharge up to $20 \%$ of SOC, considering the load profile without any wind power production. Table 3 displays the autonomy time of each solution.

Fig. 12 confirms the example of Fig. 11 by illustrating a major trend: optimization of TCO strongly limits variations of battery SOC (reduced values of DOD) in order to enhance its lifetime. Results would have been completely different if the cycling was not taken into account through the system TCO. In such a case, the whole range of DOD would be exploited with deep discharge cycles.

The analysis of the results summarized in Table 2 illustrates that some optimized solutions with different characteristics have almost the same TCO. The solutions indexed 15(a), 15(b) $\left(P_{W T}=15 \mathrm{~kW}\right)$ and $16(\mathrm{a}), 16(\mathrm{~b})\left(P_{W T}=16 \mathrm{~kW}\right)$ correspond with the cheapest battery owning cost $C_{B A T}$ among others configurations. The choice of the solution indexed 13 is optimal in terms of TCO, but nearly equivalent and surely not the most relevant solution regarding other criteria as the system autonomy. Fig. 12 shows the curves of the probability density functions ( $p d f$ ) of the number of cycles versus the depth of discharge (DOD) and their locations on the corresponding "cycle to failure" curve for each solution. The circle diameter on the "cycles to failure" curve is proportional to the cycle occurrence, i.e. the equivalent $p d f$. These figures show that the maximum of DOD for all solutions does not exceed $23 \%$ of the total storage capacity of the battery bank. These results explain why there is a trend to increase the number of battery cells in the solution Sol 15(a) compared with the solution Sol 16(a): this is obviously to further expand the total storage capacity of the battery bank and to reduce subsequently deep discharge cycles therefore enhancing the lifetime.

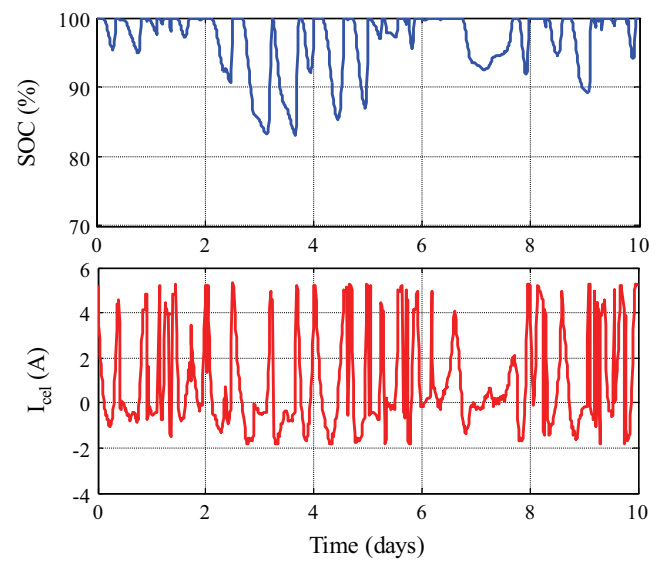

Fig. 11. $S O C$ and $I_{c e l}$ evolutions for the optimal solution.

Table 3

Time autonomy of quasi-equivalent optimal solutions.

Sol 16(a) Sol 16(b) Sol 12 Sol 13(a) Sol 13opt Sol 15(a) Sol 15(b)

\begin{tabular}{llllllll}
\hline$T_{\text {aut }}(\mathrm{h})$ & 5 & 6 & 6.2 & 6.4 & 6.6 & 7.1 & 8.1 \\
\hline
\end{tabular}




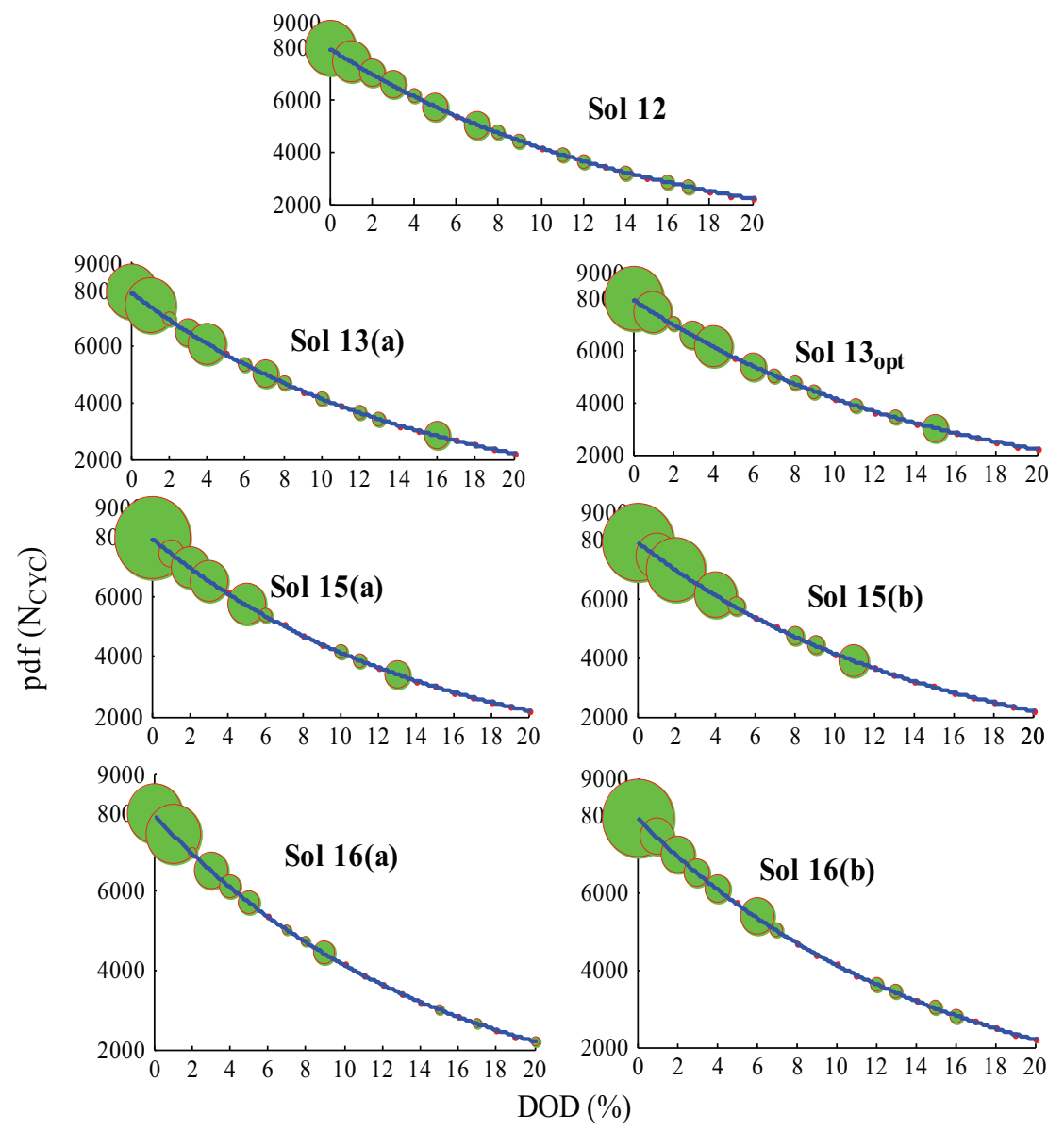

Fig. 12. $p d f$ of $N_{C Y C}$ versus $D O D$ on cycle to failure curve of each solution.

Table 4

Wind speed profiles characteristics.

\begin{tabular}{llllllr}
\hline & $c$ & $k$ & $V_{\min }$ & $V_{\max }$ & $\langle V\rangle$ & $\left\langle V^{3}\right\rangle$ \\
\hline$V_{\text {ref }}$ & 9.5 & 2.3 & 0.1 & 25 & 8.3 & 1195 \\
$V_{1}$ & 9 & 2 & 0.04 & 25.3 & 8 & 867 \\
$V_{2}$ & 10 & 2 & 0.04 & 31.6 & 8.9 & 1189 \\
$V_{3}$ & 12 & 2 & 0.1 & 34.5 & 10.8 & 2072 \\
\hline
\end{tabular}

Furthermore, at equivalent system cost, it is certainly preferable to dispose of a greater storage capacity in order to ensure load demands during longer periods without wind (i.e. autonomy Table 3). More generally, it is interesting to analyze these solutions by sensitivity analysis versus changes of environmental data (wind speed and load) then to rebuild the optimization problem to choose a robust and optimal solution.

\subsection{Sensitivity analysis of optimal solutions versus environmental} data variations

This section is devoted to the sensitivity analysis of the equivalent optimal solutions presented in Fig. 10 versus environmental input changes (i.e. wind speed and load profile variations) with the aim of identifying the most robust solutions.

\subsubsection{Sensitivity versus wind speed profile changes}

Equivalent optimal solutions represented in Fig. 10 have been obtained for a particular wind speed compact profile $\left(V_{\text {ref }}\right)$ (see

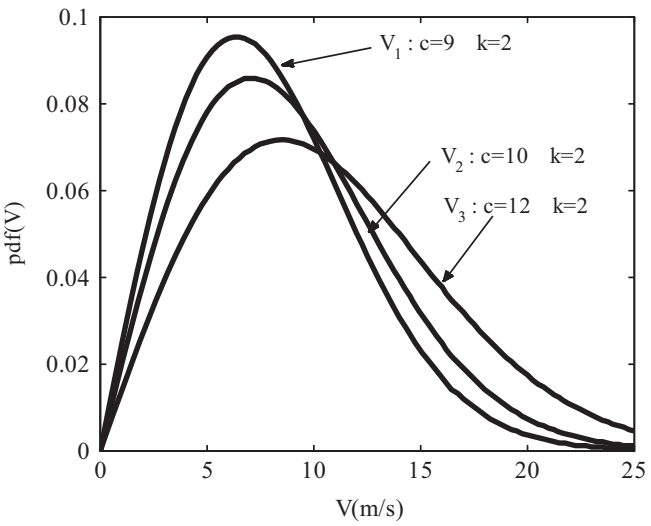

Fig. 13. Probability distribution functions of the wind speed profiles.

Fig. 3). $V_{\text {ref }}$ distribution corresponds to the characteristics of a Weibull law with a scale factor $c=9.5 \mathrm{~m} / \mathrm{s}$ and a shape factor $k=2.3$. Here, we aim at analyzing solution robustness versus statistic characteristics mentioned in Table 4.

For this purpose, three particular time profiles of wind speed with 200 days duration are generated from different Weibull distributions $\left(V_{1}, V_{2}, V_{3}\right)$ as displayed in Fig. 13 and characterized in Table 4.

Table 5 gives the number of cycles over 20 years $N_{C Y C}$, the battery bank cost $C_{B A T}$ and the TCO of several equivalent optimal solutions for each wind speed profile. These results show that the solution Sol 15(b) is the most robust in terms of TCO change: (Sol 15(b) remains lower than the one obtained with other solutions whatever the wind conditions. This robustness is partly due to the 
Table 5

Wind speed profile variations results.

\begin{tabular}{|c|c|c|c|c|c|c|c|c|}
\hline & & Sol 16(a) & Sol 16(b) & Sol 12 & Sol 13(a) & Sol $13_{\text {opt }}$ & Sol 15(a) & Sol 15(b) \\
\hline \multirow[t]{3}{*}{$V_{\text {ref }}$} & $N_{c y c}$ & 714 & 594 & 622 & 602.98 & 589 & 520 & 452 \\
\hline & $C_{B A T}(\mathrm{k} €)$ & 84.1 & 84.2 & 91.1 & 89.7 & 89 & 86.2 & 85.8 \\
\hline & TCO $(\mathrm{k} €)$ & 114.32 & 114.40 & 114.38 & 114.86 & 114.25 & 114.74 & 114.37 \\
\hline \multirow[t]{3}{*}{$V_{1}$} & $N_{c y c}$ & 1015 & 829 & 995 & 924 & 900 & 728 & 623 \\
\hline & $C_{B A T}(\mathrm{k} €)$ & 119 & 117 & 145 & 137 & 136 & 120 & 118 \\
\hline & TCO $(\mathrm{k} €)$ & 149 & 147 & 169 & 162 & 161 & 149 & 146 \\
\hline \multirow[t]{3}{*}{$V_{2}$} & $N_{c y c}$ & 846 & 659 & 806 & 752 & 736 & 582 & 480 \\
\hline & $C_{B A T}(\mathrm{k} €)$ & 99 & 93 & 118 & 111 & 111 & 96 & 91 \\
\hline & TCO $(\mathrm{k} €)$ & 129 & 123 & 141 & 137 & 136 & 124 & 119 \\
\hline \multirow[t]{3}{*}{$V_{3}$} & $N_{c y c}$ & 653 & 455 & 557 & 499 & 492 & 402 & 340 \\
\hline & $C_{B A T}(\mathrm{k} €)$ & 76 & 64 & 81 & 74 & 74 & 66 & 64 \\
\hline & TCO $(\mathrm{k} €)$ & 107 & 94 & 104 & 99 & 99 & 95 & 92 \\
\hline
\end{tabular}

Table 6

Wind speed profile $V$ characteristics.

\begin{tabular}{ccccccc}
\hline & $c$ & $k$ & $V_{\min }$ & $V_{\max }$ & $\langle V\rangle$ & $\left\langle V^{3}\right\rangle$ \\
\hline$V$ & 9.5 & 2.3 & 0.18 & 25.67 & 8.41 & 914 \\
\hline
\end{tabular}

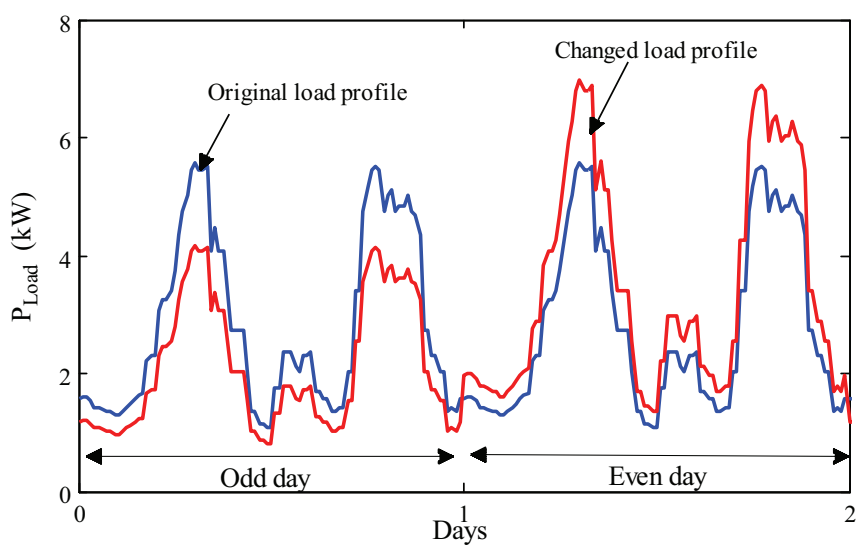

Fig. 14. Load profile changes.

battery capacity of the Sol 15 (b) $\left(N_{c e l \_}=79\right)$ which is the highest among all other solutions.

\subsubsection{Sensitivity versus load profile changes}

The sensitivity analysis of the optimal solutions versus load profile is performed by considering an actual wind profile of one year duration $(V)$ whose characteristics are given in Table 6 . Changes made with respect to the original load profile consist in inserting a variation of $25 \%$ of load power during the even days and $-25 \%$ during odd days (Fig. 14).

Table 7 shows that the Sol 15(b) remains the most robust solution in terms of TCO versus variations of load profile. As mentioned in the case of wind speed profile variations, this is explained by the highest storage capacity.

Beyond this sensitivity analysis, we can guess that the solution with the highest battery capacity (Sol 15 (b)) is also the most autonomous in case of wind drops: it is subsequently the most reliable and relevant for this application.

\section{Conclusion}

This paper illustrates a systemic optimization approach devoted to the optimal design of a full passive WT with storage
Table 7

Sensitivity versus load profile variations.

\begin{tabular}{|c|c|c|c|c|c|c|c|c|}
\hline & $\begin{array}{l}\text { Sol } 16 \\
\text { (a) }\end{array}$ & $\begin{array}{l}\text { Sol } 16 \\
\text { (b) }\end{array}$ & $\begin{array}{l}\text { Sol } \\
12\end{array}$ & $\begin{array}{l}\text { Sol } 13 \\
\text { (a) }\end{array}$ & $\begin{array}{l}\text { Sol } \\
13_{\text {opt }}\end{array}$ & $\begin{array}{l}\text { Sol } 15 \\
\text { (a) }\end{array}$ & $\begin{array}{l}\text { Sol } \\
15(b\end{array}$ & \\
\hline \multirow{3}{*}{$\begin{array}{l}\text { Original } \\
\text { profile }\end{array}$} & $N_{c y c}$ & 824 & 655 & 842 & 761 & 746 & 578 & 495 \\
\hline & $\begin{array}{l}C_{B A T} \\
(\mathrm{k} €)\end{array}$ & 97 & 92 & 123 & 113 & 112 & 95 & 94 \\
\hline & $\begin{array}{l}\text { TCO } \\
(\mathrm{k} €)\end{array}$ & 127 & 122 & 146 & 138,4 & 138 & 124 & 122 \\
\hline \multirow{3}{*}{$\begin{array}{l}\text { Modified } \\
\text { profile }\end{array}$} & $N_{c y c}$ & 791 & 650 & 811 & 746 & 728 & 573 & 479 \\
\hline & $\begin{array}{l}C_{B A T} \\
(\mathrm{k} €)\end{array}$ & 93 & 92 & 118 & 111 & 110 & 94 & 90 \\
\hline & $\begin{array}{l}\text { TCO } \\
(\mathrm{k} €)\end{array}$ & 123 & 122 & 142 & 136 & 135 & 123 & 119 \\
\hline
\end{tabular}

dedicated to stand alone applications (here for rural electrification purpose). System environment, especially wind and load conditions is integrated in the systemic design by optimization. The integrated optimal design problem was divided into two optimization processes: a local optimization which aims at designing a set of optimized WT in order to constitute a manufacturer range to be used in the second optimization process dedicated to the whole system design. The systemic optimization objective is to minimize the total owning system cost, integrating simultaneously WT and battery costs by taking account of the number of device change due to cycling effects. It is interesting to note that such a systemic vision of the TCO over the whole life cycle (here 20 years) leads to oversize batteries in order to reduce DODs (lower than 20\%) in order to reduce the number of device changes over the 20 years. Optimal results were analyzed and discussed then completed by a sensitivity analysis which has compared several selected solutions previously considered as quasi-equivalent. The sensitivity of these quasi-optimal solutions has been analyzed versus changes of environmental data (wind speed and load profiles variations) showing that solutions with highest storage capacity were the most relevant, being the most robust and also the most autonomous in case of lack of wind. The availability of the developed methodology was successfully demonstrated with the considered environmental data and it is appropriated for other acquired sets of experiment data to find consistently the optimal generation system design.

\section{Acknowledgment}

This work was supported by the Tunisian Ministry of High Education, Research and Technology; CMCU 12 G1103 and INPT SMI Projects. 
Table A1

\begin{tabular}{lll}
\hline Turbine: rated power & Radius $(\mathrm{m})$ & Friction coefficient $(\mathrm{N} \mathrm{m} \mathrm{s} / \mathrm{rd})$ \\
\hline Reference: $1.7 \mathrm{~kW}$ & 1.25 & 0.025 \\
$T_{1}: 1$ & 0.95 & 0.0087 \\
$T_{2}: 2$ & 1.35 & 0.034 \\
$T_{3}: 3$ & 1.66 & 0.07 \\
$T_{4}: 4$ & 1.91 & 0.13 \\
$T_{5}: 5$ & 2.14 & 0.21 \\
$T_{6}: 6$ & 2.34 & 0.31 \\
$T_{7}: 7$ & 2.53 & 0.42 \\
$T_{8}: 8$ & 2.71 & 0.55 \\
$T_{9}: 9$ & 2.87 & 0.70 \\
$T_{10}: 10$ & 3.03 & 0.86 \\
$T_{11}: 11$ & 3.17 & 1.04 \\
$T_{12}: 12$ & 3.32 & 1.24 \\
$T_{13}: 13$ & 3.45 & 1.46 \\
$T_{14}: 14$ & 3.58 & 1.69 \\
$T_{15}: 15$ & 3.71 & 1.94 \\
$T_{16}: 16$ & 3.83 & 2.21 \\
\hline
\end{tabular}

Table A2

\begin{tabular}{llcl}
\hline PMSG: rated power $(\mathrm{kW})$ & Flux $(\mathrm{Wb})$ & Resistance $(\mathrm{m} \Omega)$ & Inductance $(\mathrm{mH})$ \\
\hline Reference: 1.7 & 0.20 & 12626 & 1.34 \\
$G_{1}: 1$ & 0.15 & 278.4 & 1.57 \\
$G_{2}: 2$ & 0.21 & 94.3 & 1.36 \\
$G_{3}: 3$ & 0.28 & 60.9 & 1.53 \\
$G_{4}: 4$ & 0.33 & 40.4 & 1.5 \\
$G_{5}: 5$ & 0.35 & 26.5 & 1.33 \\
$G_{6}: 6$ & 0.42 & 24.2 & 1.55 \\
$G_{7}: 7$ & 0.41 & 15.6 & 1.22 \\
$G_{8}: 8$ & 0.47 & 14.6 & 1.37 \\
$G_{9}: 9$ & 0.53 & 13.7 & 1.51. \\
$G_{10}: 10$ & 0.47 & 8.3 & 1.05. \\
$G_{11}: 11$ & 0.51 & 7.9 & 1.14. \\
$G_{12}: 12$ & 0.56 & 7.6 & 1.22. \\
$G_{13}: 13$ & 0.61 & 7.3 & 1.3 \\
$G_{14}: 14$ & 0.65 & 7 & 1.38 \\
$G_{15}: 15$ & 0.7 & 6.8 & 1.46 \\
$G_{16}: 16$ & 0.75 & 6.6 & 1.54 \\
\hline
\end{tabular}

\section{Appendix}

See Tables A1 and A2.

\section{References}

[1] International Energy Agency, World Energy Outlook; 2009.

[2] Weisser D. On the economics of the electricity consumption in small island developing states: a role for renewable energy technologies? Energy Policy 2004:32(1):127-40.

[3] Nakata T, Kubo K, Lamont A. Design for renewable energy systems with application to rural areas in Japan. Energy Policy 2005;33(2):209-19.

[4] Castle JA, Kallis JM, Marshall NA, Moite SM. Analysis of merit of hybrid wind/ photovoltaic concept for stand alone systems. In: Proceedings of 15th IEEE PV specialists; 1981.

[5] Nayer CV, Phillip SJ, James WL. Novel wind/diesel/battery hybrid energy system. Solar Energy 1993;51(1):65-8.

[6] Borowy BS, Salameh ZM. Optimum photovoltaic array size for a hybrid wind/ PV system. IEEE Transactions on Energy Conversion 1994:9(3):482-8.

[7] Bagul AD, Salameh ZM, Borowy BS. Sizing of a stand-alone hybrid windphotovoltaic system using a three-event probability density approximation. Solar Energy 1996;56(4):323-36.

[8] Borowy BS, Salameh ZM. Methodology for optimally sizing the combination of a battery bank and PV array in a Wind/PV hybrid system. IEEE Transactions on Energy Conversion 1996;11(2):367-75.

[9] Spiers DJ, Rasinkoski AD. Limits to battery lifetime in photovoltaic applications. Solar Energy 1996;58:147-54.
[10] Bernard-Agustín JL, Dufo-Lopez R, Rivas-Ascaso DM. Design of isolated hybrid systems minimizing costs and pollutant emissions. Renewable Energy 2006;31(14):2227-44.

[11] Senjyu T, Hayashi D, Yona A, Urasaki N, Funabashi T. Optimal configuration of power generating systems in isolated island with renewable energy. Renewable Energy 2007;32:1917-33.

[12] Belfkira R, Nichita C, Reghem P, Barakat G. Modeling and optimal sizing of hybrid energy system. In: Proceedings of international power electronics and motion control conference (EPE-PEMC). Poznan, Poland; 1-3 September 2008.

[13] Barkirtzis AG, Dokopoulos PS, Gavanidous ES, Ketselides MA. A probabilistic costing method for the evaluation of the performance of grid-connected wind arrays. IEEE Transactions on Energy Conversion 1989;4(1):99-107.

[14] Abouzar I, Ramakumar R. Loss of power supply probability of stand-alone wind electric conversion system: a closed form solution. IEEE Transactions on Energy Conversion 1991;6(1):445-52.

[15] Diaf S, Diaf D, Belhamel M, Haddadi M, Louche A. A methodology for optimal sizing of autonomous hybrid PV/wind system. Energy Policy 2007;35 (11):5708-18.

[16] Eftichios K, Doinissia K, Antonis P, Kostas K. Methodology for optimal sizing of stand alone photovoltaic/wind generator system using genetic algorithm. Solar Energy 2006;80:1072-88.

[17] Protogeropoulos C, Brinkworth BJ, Marshall RH. Sizing and techno-economical optimization for hybrid solar PV/wind power systems with battery storage. International Journal of Energy Research 1997;21:465-79.

[18] Senjyu T, Hayashi D, Urasaki N, Funabashi T. Optimum configuration for renewable generating system in residence using genetic algorithm. IEEE Transactions on Energy Conversion 2006;21(2).

[19] Lim JH. Optimal combination and sizing of a new and renewable hybrid generation system. International Journal of Future Generation Communication and Networking 2012;5(2):43-59.

[20] Saltelli A, Tarantola S. On the relative importance of input factors in mathematical models: safety assessment for nuclear waste disposal. Journal of American Statistical Association 2002;97(459):702-9.

[21] Saltelli A, Tarantola S, Campolongo F, Ratto M. Sensitivity analysis in practice. A guide to assessing scientific models. Probability and Statistics Series. John Wiley \& Sons Publishers; 2003.

[22] Paenke I, Branke J, Jin Y. Efficient search for robust solutions by means of evolutionary algorithms and fitness approximation. IEEE Transactions on Evolutionnary Computation 2006;10(4):405-20.

[23] Wiesmann D, Hammel U, Back T. Robust design of multilayer optical coatings by means of evolutionary algorithms. IEEE Transactions on Evolutionary Computation 1998;2(4):162-7.

[24] Yamaguchi Y, Arima T. Aerodynamic optimization for the transonic compressor stator blade in optimization in industry. In: Parmee IC, Hajela P, editors. Springer; 2002. p. 163-72.

[25] Lee KH, Eom IS, Park GJ, Lee WI. Robust design for unconstrained optimization problems using Taguchi method. AIAA Journal 1996;34(5):1059-63.

[26] Lee KH, Park GJ. Robust optimization considering tolerances of design variables. Computers and Structures Journal 2001;79:77-86.

[27] Belouda M, Belhadj J, Sareni B, Roboam X. Battery sizing for a stand alone passive wind system using statistical techniques. In: Proceedings of 8th international multi-conference on systems, signals and devices. Sousse, Tunisia; 2011.

[28] Mirecki A, Roboam X, Richardeau F. Architecture cost and energy efficiency of small wind turbines: which system tradeoff? IEEE Transactions on Industrial Electronics 2007;54(1):660-70.

[29] Tran DH, Sareni B, Roboam X, Espanet C. Integrated optimal design of a passive wind turbine system: an experimental validation. IEEE Transactions on Sustainable Energy 2010;1(1):48-56.

[30] Fefermann Y, Randi SA, Astier S, Roboam X. Synthesis models of PM Brushless Motors for the design of complex and heterogeneous system, EPE'01. Graz, Austria; September 2001.

[31] Sareni B, Abdelli A, Roboam X, Tran DH. Model simplification and optimization of a passive wind turbine generator. Renewable Energy Journal 2009;34: 2640-50.

[32] Belouda M, Belhadj J, Sareni B, Roboam X, Jaafar A. Synthesis of a compact wind profile using evolutionary algorithms for wind turbine system with storage, MELECON'. Hammamet, Tunisia; Mars 2012.

[33] 〈http://www.houseofbatteries.com/pdf/NP38-12〉.

[34] 〈http://www.eaglewestwind.com/〉.

[35] Drouilhet S, Johnson BL. A battery life prediction method for hybrid power applications. In: Proceedings of 35th AIAA aerospace sciences meeting and exhibit. Reno, Etats-Unis; January 1997.

[36] Ruddella AJ, Duttona AG, Wenzlb H, Ropeterb C, Sauerc DU, Mertend J, et al. Analysis of battery current microcycles in autonomous renewable energy systems. Journal of Power Sources 2002;136:123-4.

[37] Downing SD, Socie DF. Simple rainflow counting algorithms. International Journal of Fatigue 1982;4:31. 